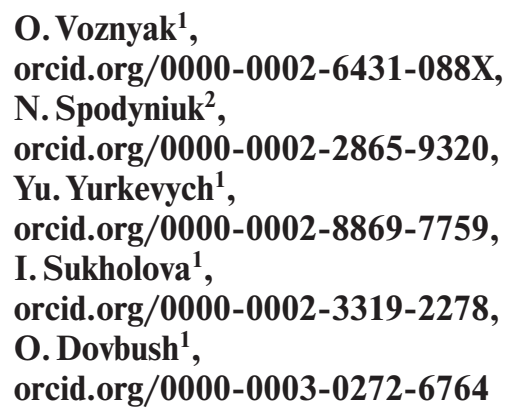

1 - Lviv Polytechnic National University, Lviv, Ukraine
2 - National University of Life and Environmental Sciences
of Ukraine, Kyiv, Ukraine, e-mail: n_spoduniuk@meta.ua

\title{
ENHANCING EFFICIENCY OF AIR DISTRIBUTION BY SWIRLED-COMPACT AIR JETS IN THE MINE USING THE HEAT UTILIZATORS
}

Purpose. Improving the efficiency of air distribution by swirling-compact jets due to creating a dynamic microclimate in the mine when using supply and exhaust recuperators with utilization of heat of exhaust air. To achieve this goal, the task was to conduct full-scale experimental studies on the supply and exhaust recuperator, which forms swirling-compact jets, and obtain the calculated dependences for the theoretical solution of air distribution in the mine, as well as to establish the interrelation of air parameters to ensure optimal thermal condition of the mine.

Methodology. A supply and exhaust recuperator was selected for the study on air distribution by a swirling-compact jet in stationary and alternating modes. Numerical simulation of air flow in the mine in stationary mode is performed. The simulation was performed using the $k-\varepsilon$ turbulence model.

Findings. Analytical graphical dependences for calculation of air distribution by a swirling-compact jet are received, which allow determining the velocity of air movement in compressed conditions of the mine in an alternating mode. Based on the numerical modeling and comparison of known dependences with those obtained experimentally, the correction coefficient of compression depending on the current coordinate is determined. The twisting effect changes the direction of the jet axis and is maximal at point $A$ with relative coordinates $\bar{x}_{A}=0.6$ and $\bar{y}_{A}=0.2$; its maximum is in the area $\bar{z}=0.7-0.8$, given the presence of pulsations and instability of the regime. The theoretically obtained results are compared with the experimental data and a correction factor is set depending on the current coordinate, the maximum value of which is $k_{t w}=1.78$.

Originality. The expediency is proved of application of swirling-compact jets formed by the recuperator with utilization of heat of exhaust air in an alternating mode in aerodynamic and energy saving aspects. These measures will provide comfortable conditions in the mine and achieve energy savings.

Practical value. The use of supply and exhaust recuperators with utilization of the heat of exhaust air will allow designing energy-saving air distribution schemes in the system of sectional ventilation for small-sized mines with provision of standard parameters of air in an alternating mode.

Keywords: mine, swirling-compact jets, supply and exhaust recuperator, air distribution

Introduction. The issues of energy saving, energy accounting and consumption management are extremely relevant. In the context of the acute economic crisis, the careful use of energy is an important priority of European economic policy. Recently, the role of ventilation in creating conditions for high production in mines has increased. Requirements for continuous improvement of occupational safety and intensification of production processes set a number of new challenges for mining ventilation. Ensuring regulatory air parameters that create a comfortable microclimate is an important task of the mining industry [1]. High concentration of $\mathrm{CO}_{2}$ and other gases in the mine leads to deterioration of health and reduced efficiency of workers [2]. To the mine air, strict requirements are set, because if it is not ventilated, it can be explosive [3]. There is no doubt that energy consumption for the needs of the ventilation system must be reduced as a result of energy efficiency measures [4]. To achieve the maximum effect, it is necessary to determine the economically feasible level of thermal protection of microclimate systems, which should be optimal both thermally and economically. The choice of energy-saving operating conditions of existing mine ventilation systems is often made taking into account economic aspects [5], which allows establishing optimum possibilities of system, and, accordingly, energy-saving conditions of their operation.

To install sectional ventilation of the mine one of the important tasks is to create an effective organization of air ex-

(C) Voznyak O., Spodyniuk N., Yurkevych Yu., Sukholova I., Dovbush O., 2020 change and, in particular, air distribution [6]. At the same time the normalized velocity of air movement in a working area and normalized excess temperature on the flow axis of the inflow jet have to be provided. These values are normalized for different ventilation systems and non-compliance with them can both cause deterioration of human health and affect the operation of equipment. The choice of the method for inflow air supply depends on the purpose of the room, technological processes which take place in it, and other features [6].

Literature review. At designing microclimate systems for mines, the main task is to create comfortable conditions in the working area. Labor efficiency and quality of extracted coal depend on the microclimate in the mines. Of great importance is the air exchange in the mine, in particular, the choice of the most efficient method of air distribution [7]. The advantages and disadvantages of mechanical and natural ventilation are considered, also different ventilation schemes and the amount of air supply to the mine and the efficiency of air distribution from different heights are described. However, when considering the mining industry, the issue of air exchange in small facilities, such as mining, was not considered, because in them air distribution is a rather difficult task.

There is a large number of various designs of air distributors with high intensity of attenuation of parameters (velocity $v$ and temperature $t$ ) of supply air [8]. However, the air distributors for the air supply by swirling-compact jets were not analyzed. A characteristic feature of the inflow jets created by such devices is the increased turbulence compared to direct-flow jets. The attenuation intensity of the parameters is characterized by 
the values of the attenuation coefficients of velocity $m$ and temperature $n$. For small mines, the air supply directly to the working area was not considered. The actual task in this case will be to ensure the normalized temperature of the supply air.

At choosing the method for inflow air supply must take into account the geometric dimensions of the mine, location of equipment, sources of heat and hazards, as well as the possibility of laying supply jets on various surfaces [9]. However, the issue of supply inflow air to the mines and the possibility of laying them on the surface of different configurations remained unresolved.

For objects of small volume and height, there are difficulties in supplying a significant amount of air and ensuring a low velocity of air movement in the working area. For this purpose air-distributing devices with a small coefficient of attenuation of velocity are suitable [10] and at supply of inflow air in a working area - with small initial velocity. In this case, there are effective air distribution devices with a sufficient air distribution area, low initial velocity, and low coefficient of its attenuation [10]. The use of air distributors with high uniformity of the air flow rate, leaving a nozzle and low coefficients of attenuation of parameters of a supply stream in many cases is the optimal solution for proper air distribution in mines.

It is known that the variable mode of air supply has a positive effect on human well-being and efficiency. The collision of oncoming jets, twisting [11] and laying of inflow air streams [9] are considered. In the considered schemes of air distribution the energy-efficient variant is air supply by twisted-compact jets. However, in mines for the adaptation of the thermoregulation apparatus, improving the well-being and reducing fatigue of workers, it is hygienically justified to change one of the parameters, for example, the temperature or velocity of air movement, according to the periodic law, that is to create a dynamic microclimate. The authors did not analyze the efficiency of air distribution in non-stationary mode.

Using the twist effect [11] and flooring effect [9] of jets is an effective way to increase their turbulence; however, flooring increases the range of the jet, which is undesirable for small mines. Mutual attenuation of pulses when twisting jets leads to the formation of turbulent air flow, which comes from the air distributor to the service area.

An extremely important aspect in the study of jet streams is the numerical simulation in the stationary mode [12]. In article [13] fully developed turbulence is described that occurs in mines, in straight channels of non-circular cross-section. The techniques given in [14] are used for modeling of air streams in the supply and exhaust recuperator. The methods for numerical modeling of the air flow in the room with different models of turbulence were also analyzed [15]. Turbulence models were compared, including a linear viscosity model, a nonlinear version of the same model, as well as a seven-level full-second level [16]. Direct numerical simulation (DNS) was used to study the separated and rapidly attached turbulent boundary layer [17]. Was investigated the thrust reduction for the developed turbulent boundary layer, flowing through an array of shallow dimples, with a diameter comparable to the thickness of the boundary layer [18]. Reynolds numbers were not high, but insignificant. As can be seen from the methods, it is advisable to use the $k-\varepsilon$ model of turbulence [19].

To calculate the system of Navier-Stokes equations averaged over Reynolds, the analysis of the corresponding mathematical models was carried out [20].

An important priority of European economic policy is the careful use of energy. The countries have a large-scale policy in the field of energy saving. These tasks are complex and cover both the legal framework and technical innovations. One of the effective ways to reduce energy consumption for ventilation is introduction of energy efficient systems $[4,5]$. Due to increasing the efficiency of air distribution by vorticity and dissemination of air jets, it is possible to ensure the normative parameters of air in production areas [11].
Unsolved aspects of the problem. Based on a review of the literature, it is stated that:

- there is a need to develop a method for calculating the compact jet using the effect of twisting, namely twisted-compact air flow;

- the properties of the flow of jets in an alternating mode are insufficiently studied, because with providing comfortable conditions indoors creation of a dynamic microclimate in a mine plays an important role;

- there is no numerical simulation of the flow of swirlingcompact ventilation jets;

- insufficient attention is paid to energy saving issues in the mine in general and the use of heat recovery units in particular.

Purpose. The aim of the work is to increase the efficiency of air distribution by swirling-compact jets due to creation of a dynamic microclimate in a mine at application of supply and exhaust recuperators with utilization of heat of exhaust air.

To achieve this goal, the following tasks were set:

- to conduct full-scale experimental studies on the supply and exhaust recuperator, which forms swirling-compact jets, and obtain calculated dependences for the theoretical solution of air distribution in a mine;

- to establish the relationship of air parameters to ensure optimal thermal condition of the mine;

- to compare the theoretically obtained results with experimental data and establish correction factors.

Materials and methods of research on air distribution by a twisted-compact jet in stationary and alternating modes. A supply and exhaust recuperator was chosen to study the air distribution by a swirling-compact jet in stationary and alternating modes. It should be noted that the supply and exhaust recuperators (Fig. 1) have a characteristic design feature. The axial fan is located at a distance from the air outlet that is less than 5 diameters of the supply pipe. This factor causes the twisting of the incoming compact air jet, that is, the air flow comes out of the hole in a twisted-compact jet. As a result, the damping coefficients of the velocity and temperature of the supply air stream decrease, that is, the aerodynamic performances of the device are improved. This allows reducing the performance of the ventilation system and the metal consumption of the system as a whole.

Another positive feature of the device is an ability to control the flow of supply air and heat utilization for its heating.

A model Belimo LM24A (Switzerland) has been developed to create a dynamic microclimate in the room with the help of a built-in electric drive (Fig. 2). This makes it possible to change the air flow in the air ducts, and hence to supply inflow air in an alternating mode. This ensures a dynamic microclimate in the working area.

The connection of the electric drive, which is controlled from the automation unit, makes it possible to smoothly adjust the total air flow in the air duct. The flow of supply air through the air distributors changes smoothly, the period is set by the automation unit, thus creating a changing microclimate in the

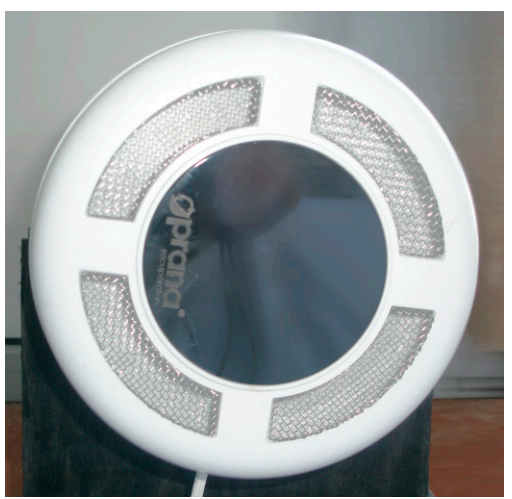

Fig. 1. Supply and exhaust recuperator 


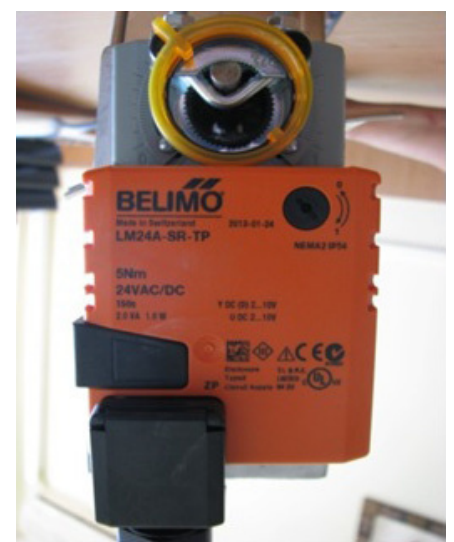

Fig. 2. Electric drive Belimo LM24A

working area, which makes it possible to improve sanitary and hygienic conditions in the mine.

The results of analytical and experimental studies of air distribution by twisted-compact jet. Stationary jet flow mode. The calculation of free compact jets is performed according to a known formula

$$
v_{x}=v_{o} \frac{m \sqrt{F_{o}}}{x},
$$

where $v_{0}$ and $v_{x}$ are respectively the initial and axial velocity of the air stream, $\mathrm{m} / \mathrm{s} ; x$ is a current coordinate, $\mathrm{m} ; F_{0}$ is an area of the air outlet, $\mathrm{m}^{2} ; m$ is the coefficient of attenuation of the air flow velocity.

As is known, in the case of compressed jets, a compression ratio is introduced $k_{c}$, and the calculation formula looks like this

$$
v_{x}=v_{o} \frac{m k_{c} \sqrt{F_{o}}}{x} .
$$

The paper similarly proposes to introduce a correction twist coefficient for jet $k_{t w}$ for swirling-compact jets and perform the calculation similarly to those for compact jets. Given formula (1), we obtain the dependence

$$
v_{x}=v_{o} \frac{m k_{t w} \sqrt{F_{\hat{\imath}}}}{x} .
$$

Then the task arises of determining the twist coefficient $k_{t w}$ experimentally. Due to the twist, the axis of the jet will not be directed along $O x$, but at some angle $\alpha$. The actual axis of the jet will be $O z$, at which maximum velocities will be observed. Based on this, it is stated that the twist factor will be greater than one $\left(k_{t w}>1\right)$.

It is advisable to accept the following simplifications and assumptions:

- the property of symmetry is valid;

- a flat problem is considered;

- the twist factor depends only on the current coordinate.

To generalize, it is necessary to take the calculated values in dimensionless form.

Experimental studies were performed on a serial sample of the recuperator with the following characteristics: supply $115 \mathrm{~m}^{3}$ /hour, exhaust $-105 \mathrm{~m}^{3}$ /hour. The scheme of the experimental setup for the research is presented in Fig. 3. These studies allowed us to assess both the thermal and aerodynamic characteristics of the device.

Changing the performance of the supply system was carried out by adjusting the fan air flow. The design of the recuperator provides 9 modes of operation of the fan, switching which is carried out by means of the remote control. Measurements of air velocity $v$ were performed with a thermoelectric anemometer Testo - 405 using a coordinator with a grid of points $10 \times 10 \mathrm{~cm}$. Measurements were performed in cycles at

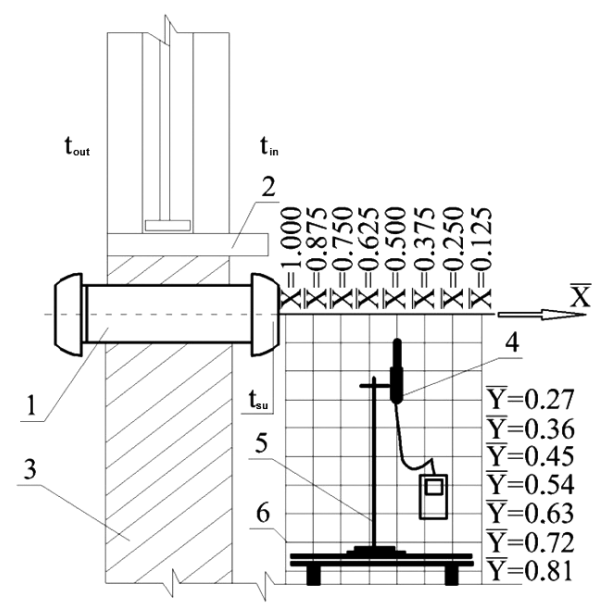

Fig. 3. Scheme of experimental installation:

1 - recuperator; 2 - window sill; 3 - outer wall; 4 - sensor of the thermoelectric anemometer Testo - 405; 5 - tripod; 6 - coordinate grid

least twice, and in case of discrepancy of results more than $10 \%$ were performed for the third time. At the same time, randomization in time was maintained. In addition, the velocity measurement at each point was performed for at least $120 \mathrm{sec}-$ onds with discrete (after 10 seconds) recording of impressions and their subsequent averaging. The air temperature in the laboratory was measured with a thermoelectric anemometer Testo -405 both before and after the experiment.

Experimental studies were performed under the following conditions and simplifications:

- the area of the recuperator holes $F_{0}=0.0025 \mathrm{~m}^{2}$;

- the flow of air flows was within $L=25-115 \mathrm{~m}^{3} /$ hour;

- the initial air velocity was within $v_{0}=1-11 \mathrm{~m} / \mathrm{s}$.

Based on the measurements of outdoor, indoor and supply air temperatures at its various costs, it is known that at lower air flow and outdoor air temperature $t_{\text {out }}>-8^{\circ} \mathrm{C}$ the utilization factor corresponds to the value stated by the manufacturer $K=$ $=0.91$. At higher values of air flow and outdoor air temperature $t_{\text {out }}<-8{ }^{\circ} \mathrm{C}$ the heat recovery coefficient is slightly lower $(K=$ $=0.85-0.87$ ).

Figs. $4-6$ show the results of measuring the velocity in the direct flow of a swirling-compact jet.

The results of the research (Fig. 4) show that due to the twisting of the direction the jet axis $O x$ changes to $O z$, which coincides with the direction of the vector $\overline{O A}$. This leads to an increase in the velocity, which becomes the value $v_{z}$, which is determined from the formula

$$
v_{z}=\sqrt{v_{x}^{2}+v_{y}^{2}} .
$$

At point A with relative coordinates $\bar{x}_{A}=0.6$ and $\bar{y}_{A}=0.2$ (Fig. 4) there is a change in the direction of the jet axis from

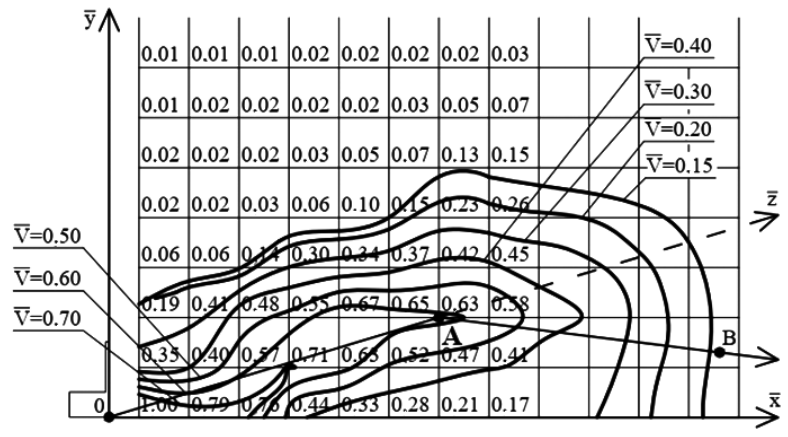

Fig. 4. The velocity field of a swirling-compact air jet 


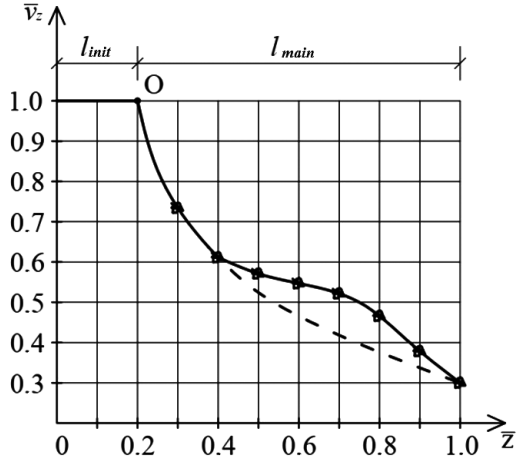

Fig. 5. The dependence of the axial velocity $v_{z}$ on the initial coordinate

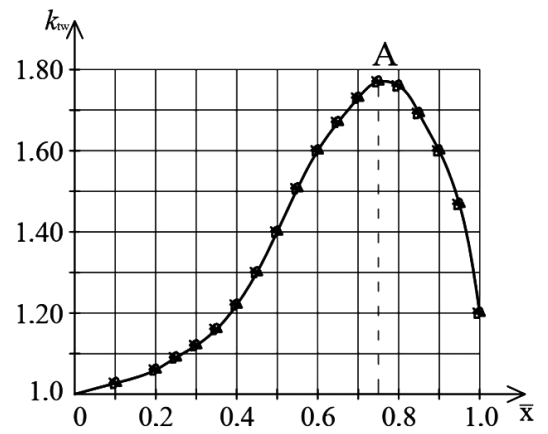

Fig. 6. Dependence of the twisting factor $k_{t w}$ for a twisted-compact jet on the current coordinate

$\overline{O A}$ to $\overline{A B}$, that is, at this point the twisting effect begins to appear.

The research results show (Fig. 5) that the initial section of the jet passes into the main section at the point $O$ at a distance $\bar{z}=0.2$, and the effect of twisting is manifested starting from the relative coordinate $\bar{z}=0.4$ and acquires its maximum in the field $\bar{z}=0.7-0.8$, given the presence of pulsations and mode instability. This is evidenced by the division of dashed and solid lines in the graph (Fig. 5).

The presence of point $\mathrm{A}$ as a maximum in the graph (Fig. 6), confirms the maximum twisting effect and the change in the direction of the axis of the twisted-compact jet at point A with the relative coordinate $\bar{x}=0.75$, which is in the specified interval $\bar{x}=0.7-0.8$.

To obtain the possibility of analytical calculations, the graph in Fig. 6 was approximated by the following dependence

$$
k_{t w}=1.22+2.7(\bar{x}-0.4)-3.8(\bar{x}-0.4)^{2} .
$$

The correction of 0.4 is explained by the fact that directly in this area the phenomenon of jet twisting begins. In this regard the particular interest is only the area $\bar{x}=0.4-0.9$, because in the area of $0.9-1.0$ the jet is already attenuating.

Due to dependence (5), it is possible to determine the point of maximum analytically. To do this, the expression (5) is differentiated by defining the derivative of the function $k_{t w}, \bar{x}$

$$
k_{t w}=2.7-7.6(\bar{x}-0.4) .
$$

Equating the result to zero, we obtain (7)

$$
2.7=7.6(\bar{x}-0.4) \text {. }
$$

The result is $\bar{x}=0.755$. Thus, the function $k_{t w}$ has a maximum at a point with relative coordinate $\bar{x}=0.755$. As can be seen, a satisfactory convergence of results was obtained.
Alternating jet flow mode. The movement of inflow jets from the recuperator in the alternating mode is considered. This factor is reflected by the change in air flow from $L_{\min }$ to $L_{\max }$. It is assumed and simplified that the change in supply air flow occurs according to the harmonic law (8)

$$
L=A \sin \omega \tau,
$$

where $A$ is the amplitude of flow fluctuations $A=L_{\max }-L_{\text {nom }}$, and $L_{\max }$ and $L_{\text {nom }}$ respectively its maximum and nominal value.

For the use of air recirculation in air ventilation systems, the concentration of $\mathrm{CO}_{2}$ is determined indoors in the stationary mode [3], but the alternating mode is not taken into account. In this paper, the alternating mode of air supply to the room is taken into account. The change in quantity of $\mathrm{CO}_{2}$ is adopted according to the harmonic law, and the maximum amount of air and the minimum concentration of $\mathrm{CO}_{2}$ occurs simultaneously. The use of air supply to the mine in non-stationary mode allows achieving energy savings of $40 \%$ due to twisting of an air stream and $5 \%$ due to flooring [4].

Numerical simulation of the flow of a swirling-compact jet in a mine in stationary mode. Numerical simulation of air flow in the mine in stationary mode is performed. The simulation was performed using the $k-\varepsilon$ turbulence model under the following conditions: stationary traffic mode; initial velocity of the jet $v_{0}=1-11 \mathrm{~m} / \mathrm{s}$.

Fig. 7 allows visualizing at the appropriate scale the results of the study on the swirling-compact jet, which flows in the compressed conditions of a small room, which corresponds to similar conditions of mines. This figure clearly demonstrates the effect of twisting when leaking a twisted-compact jet in stationary mode, and also confirms increased intensity of attenuation of the air flow rate.

The results obtained experimentally and using the $k-\varepsilon$ stationary turbulence model are compared. A satisfactory convergence of experimentally obtained results and numerical simulations is observed.

The assumption of symmetry properties in the characteristics of the air jet is confirmed.

The attenuation coefficients of velocity and temperature, which are respectively within the limits $m=4.1-4.5$ and $n=$ $=3.5-3.9$, depending on the device modification were determined. Therefore, the recuperator provides the optimal intensity of attenuation of dynamic and thermal parameters of the swirling-compact jet from the point of view of its long-range and makes air flow sufficiently turbulized.

The reliability of the results of experimental studies was justified by checking the adequacy of the mathematical model according to Student's, Fischer's and Cochren's criteria, at the confidence interval $\alpha=0.95$.

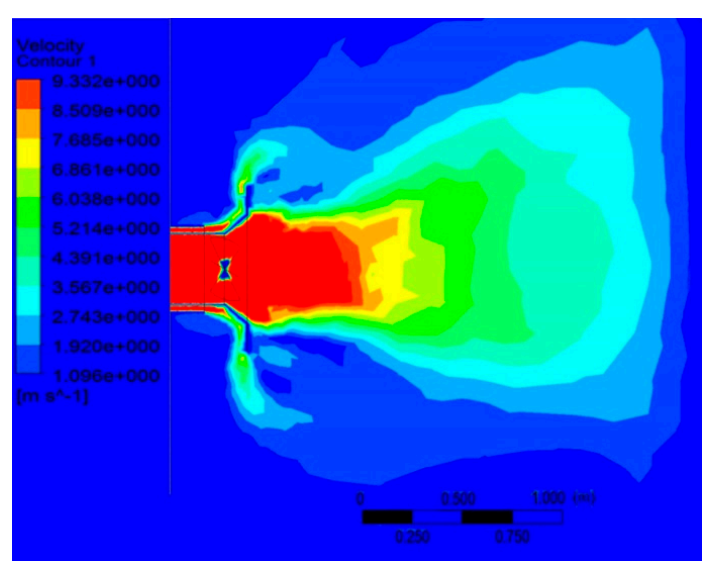

Fig. 7. Results of numerical simulation using $k-\varepsilon$ turbulence model 


\section{Conclusions.}

1. Analytical graphical dependences for calculation of air distribution by a twisted-compact stream are received; they allow determining the velocity of air movement in compressed conditions of the mine in the alternating mode; to obtain the possibility of analytical calculations, the graphs were approximated by formulas; on the basis of the carried out numerical modeling and comparison of known dependences with the ones received experimentally, the corrective coefficient of compression depending on the current coordinate is defined; the effect of twisting leads to a change in the direction of the axis of the jet and is maximum at point A with relative coordinates $\bar{x}_{A}=0.6$ and $\bar{y}_{A}=0.2$; its maximum is located in the region $\bar{z}=0.7-0.8$, considering the presence of pulsations and mode instability.

2. Use of supply and exhaust recuperators with utilization of heat of exhaust air will allow designing energy-saving air distribution schemes in the sectional ventilation system for small-sized mines with provision of normative parameters of air in the alternating mode.

3. The theoretically obtained results are compared with the experimental data and the correction factor is set depending on the current coordinate, the maximum value of which $k_{t w}=1.78$.

4. The expediency of application of swirling-compact jets both in aerodynamic and in the aspect of energy saving formed by the recuperator with utilization of heat of exhaust air, in the alternating mode, is proved. These measures will provide comfortable conditions in the mine and achieve energy savings.

5 . The research results can be used in the design of energysaving sectional air distribution schemes for small mines.

Prospects for further research in this direction. Further research should be conducted to prove the effectiveness of the proposed methods for other types of premises.

Of interest are studies on the acoustic characteristics of the proposed equipment.

In future, it is advisable to take into account the impact of production equipment and heat sources on air distribution in mines. The possible presence of local exhaust systems plays an important role in such an air distribution scheme. This can significantly affect the efficiency of the use of swirl-compact jets.

\section{References.}

1. Dovhaliuk, V., \& Mileikovskyi, V. (2018). New approach for refined efficiency estimation of air exchange organization. International Journal of Engineering and Technology (UAE), 7(3.2), 591-596. https://doi.org/10.14419/ijet.v7i3.2.14596. 2. Kapalo, P., Domnita, F., Bacotiu, C., \& Podolak, M. (2018). The influence of occupants' body mass on carbon dioxide mass flow rate inside a university classroom - case study. International Journal of Environmental Health Research, 28(4), 432-447. https://doi.org/10.1080/09603123.2018.1483010.

3. Kapalo, P., Vilceková, S., Domnita, F., Bacotiu, C., \& Voznyak, O. (2017). Determining the Ventilation Rate inside an Apartment House on the Basis of Measured Carbon Dioxide Concentrations - Case Study. The $10^{\text {th }}$ International Conference on "Environmental Engineering". Vilnius, Lithuania, Selected Papers, (pp.30-35). https://doi.org/10.3846/enviro.2017.262.

4. Spodyniuk, N., Gulai, B., Zhelykh, V., \& Shapoval, S. (2019). Leveling of pressure flow of radial ventilator in mine ventilation system. Naukovyi Visnyk Natsionalnoho Hirnychoho Universytetu, (6), 80-86. https://doi.org/10.29202/nvn$\mathrm{gu} / 2019-6 / 12$.

5. Aedah, M. J. Mahdi (2018). Energy Audit a step to effective Energy Management. International Journal of Trend in Research and Development, 5(2), 521-525. ISSN: 2394-9333.

6. Gumen, O., Dovhaliuk, V., \& Mileikovskyi, V. (2019). Geometric representation of turbulent macrostructure in 3D jets. ICGG 2018 - Proceedings of the $18^{\text {th }}$ International Conference on Geometry and Graphics, (pp. 739-745). https://doi. org/10.1007/978-3-319-95588-9_61.
7. Dovhaliuk, V., Gumen, O., Mileikovskyi, V., \& Dziubenko, V. (2018). Simplified analysis of turbulence intensity in curvilinear wall jets. FME Transactions, 46, 177-182. https:// doi.org/10.5937/fmet 1802177D

8. Voznyak, O., Yurkevych, Yu., Dovbush, O., \& Serediuk, Ya. (2019). The influence of chairs and passengers on air velocity in bus passenger compartment. Springer, Proceedings of CEE 2019, Advances in Resourse-saving Technologies and Materials in Civil and Environmental Engineering, 47, 518-525. https:// doi.org/10.1007/978-3-030-27011-7 66.

9. Gumen, O., Dovhaliuk, V., Mileikovskyi, V., Lebedieva, O., \& Dziubenko, V. (2017). Geometric analysis of turbulent macrostructure in jets laid on flat surfaces for turbulence intensity calculation. FME Transaction, 45, 236-242. https:// doi.org/10.5937/fmet1702236G

10. Andersson, H., Cehlin, M., \& Moshfegh, B. (2018). Experimental and numerical investigations of a new ventilation supply device based on confluent jets. Building and Environment, 137, 18-33. https://doi.org/10.1016/j.buildenv.2018.03.038.

11. Voznyak, O., Korbut, V., Davydenko, B., \& Sukholova, I. (2019). Air distribution efficiency in a room by a two-flow device. Springer, Proceedings of CEE 2019. Advances in Resoursesaving Technologies and Materials in Civil and Environmental Engineering, 47, 526-533. https://doi.org/10.1007/978-3-03027011-7 67.

12. Coleman, G. N., Rumsey, C.L., \& Spalart, P. R. (2018). Numerical study of turbulent separation bubbles with varying pressure gradient and Reynolds number. Journal of Fluid Mechanics, 847, 28-70. https://doi.org/10.1017/jfm.2018.257.

13. Spalart, P. R., Garbaruk, A., \& Stabnikov, A. (2018). On the skin friction due to turbulence in ducts of various shapes. Journal of Fluid Mechanics, 838, 369-378. https://doi. org/10.1017/jfm.2017.911.

14. Rumsey, C. L. (2018). The NASA juncture flow test as a model for effective CFD/experimental collaboration. 2018 Applied Aerodynamics Conference, AIAA-2018-3319. https:// doi.org/10.2514/6.2018-3319.

15. Spalart, P. R., \& Garbaruk, A. V. (2019). The Predictions of Common Turbulence Models in a Mature Vortex. Flow, Turbulence and Combustion, 102, 667-677. https://doi. org/10.1007/s10494-018-9983-6.

16. Rumsey, C. L., Carlson, J.R., \& Ahmad, N. N. (2019). Fun $3^{d}$ juncture flow computations compared with experimental data. AIAA Scitech 2019 Forum. https://doi. org/10.2514/6.2019-0079.

17. Coleman, G. N., Rumsey, C.L., \& Spalart, P. R. (2019). Numerical study of a turbulent separation bubble with sweep. Journal of Fluid Mechanics, 880, 684-706. https://doi. org/10.1017/jfm.2019.736.

18. Spalart, P. R., Shur, M., Strelets, M., Paschal, K. B., \& Wilkinson, S. P. (2019). Experimental and numerical study of the turbulent boundary layer over shallow dimples. International Journal of Heat and Fluid Flow, 78. https://doi.org/ 10.1016/j.ijheatfluidflow.2019. 108438.

19. Stefanski, D. L., Glasby, R.S., Erwin, J.T., Allmaras, S. R., Coder, J. G., \& Burgessn, N. K. (2018). A modified $\mathrm{k}-\omega$ turbulence model for finite-element CFD. 2018 Fluid Dynamics Conference. https://doi.org/10.2514/6.2018-4041.

20. Lorin, E. (2019). From structured data to evolution linear partial differential equations. Journal of Computational Physics, 393, 162-185. https://doi.org/10.1016/i.jcp.2019.04.049.

\section{Підвищення ефективності повітророзподілу закручено-компактними струменями в гірничій шахті з використанням теплоутилізаторів}

\author{
О. Т. Возняк ${ }^{1}$, Н. А. Сподинюк ${ }^{2}$, Ю. С. Юркевич ${ }^{1}$, \\ I. Є. Сухолова ${ }^{1}$, О. М. Довбуш
}


1 - Національний університет «Львівська політехніка», м. Львів, Україна

2 - Національний університет біоресурсів і природокористування України, м. Київ, Україна, e-mail: n_ spoduniuk@meta.ua

Мета. Підвищення ефективності повітророзподілу закручено-компактними струменями за рахунок створення динамічного мікроклімату в гірничій шахті при застосуванні припливно-витяжних рекуператорів з утилізацією теплоти викидного повітря. Для досягнення мети було поставлено завдання провести натурні експериментальні дослідження припливно-витяжного рекуператора, що утворює закручено-компактні струмені та отримати розрахункові залежності для теоретичного вирішення повітророзподілу в гірничій шахті, а також встановити взаємозв'язок параметрів повітряного середовища для забезпечення оптимального теплового стану шахти.

Методика. Для дослідження повітророзподілу закручено-компактним струменем у стаціонарному та змінному режимі було обрано припливно-витяжний рекуператор. Виконано числове моделювання потоку повітря в шахті у стаціонарному режимі. Моделювання проводилось за допомогою $k-\varepsilon$ моделі турбулентності.

Результати. Отримані аналітичні графічні залежності для розрахунку повітророзподілу закручено-компактним струменем, що дозволяють визначати швидкість руху повітря у стиснених умовах гірничої шахти у змінному режимі. На підставі проведеного числового моделювання та співставлення відомих залежностей з отриманими експериментально, визначено поправний коефіцієнт стиснення залежно від поточної координати. Ефект закручування призводить до зміни напрямку осі струменя та $€$ максимальним у точці $A$ з відносними координатами $\bar{x}_{A}=0,6$ та $\bar{y}_{A}=0,2$; його максимум знаходиться в області $\bar{z}=0,7-0,8$, ураховуючи наявність пульсацій і нестійкість режиму. Виконане порівняння теоретично отриманих результатів з експериментальними даними та встановлено поправний коефіцієнт у залежності від поточної координати, максимальне значення якого $k_{t w}=1,78$.

Наукова новизна. Доведена доцільність як в аеродинамічному, так і в аспекті енергоощадності, застосування закручено-компактних струменів, утворених рекуператором, з утилізацією теплоти викидного повітря, у змінному режимі. Ці заходи дадуть можливість забезпечити комфортні умови в гірничій шахті й досягнути енергоощадності.

Практична значимість. Використання припливно-витяжних рекуператорів з утилізацією теплоти викидного повітря дасть змогу проектувати енергоощадні схеми повітророзподілу в системі секційної вентиляції для малогабаритних гірничих шахт із забезпеченням нормативних параметрів повітря у змінному режимі.

Ключові слова: гірнича шахта, закручено-компактні струмені, припливно-витяжний рекуператор, повітророзподіл

\section{Повышение эффективности воздухораспределения закручено- компактными струями в горной шахте с использованием теплоутилизаторов}

\author{
О. Т. Возняк ${ }^{1}$, Н.А. Сподинюк ${ }^{2}$, Ю. С. Юркевич ${ }^{1}$, \\ И. Е. Сухолова ${ }^{1}$, О. Н. Довбуш ${ }^{1}$
}

1 - Национальный университет «Львовская политехника», г. Львов, Украина

2 - Национальный университет биоресурсов и природопользования Украины, г. Киев, Украина, e-mail: nspoduniuk@meta.ua

Цель. Повышение эффективности воздухораспределения закручено-компактными струями за счет создания динамического микроклимата в горной шахте при применении приточно-вытяжных рекуператоров с утилизацией теплоты выбросного воздуха. Для достижения цели были поставлены задачи провести натурные экспериментальные исследования приточно-вытяжного рекуператора, который образует закручено-компактные струи и получить расчетные зависимости для теоретического решения воздухораспределения в горной шахте, а также установить взаимосвязь параметров воздушной среды для обеспечения оптимального теплового состояния шахты.

Методика. Для исследования воздухораспределения закручено-компактной струей в стационарном и сменном режиме был избран приточно-вытяжной рекуператор. Выполнено численное моделирование потока воздуха в шахте в стационарном режиме. Моделирование проводилось с помощью $k-\varepsilon$ модели турбулентности.

Результаты. Получены аналитические графические зависимости для расчета воздухораспределения закручено-компактной струей, которые позволяют определять скорость движения воздуха в стесненных условиях горной шахты в сменном режиме. На основании проведенного численного моделирования и сопоставления известных зависимостей с полученными экспериментально, определен поправочный коэффициент сжатия в зависимости от текущей координаты. Эффект закручивания приводит к изменению направления оси струи и является максимальным в точке А с относительными координатами $\bar{x}_{A}=0,6$ и $\bar{y}_{A}=0,2$; его максимум находится в области $\bar{z}=0,7-0,8$, учитывая наличие пульсаций и неустойчивость режима. Выполнено сравнение теоретически полученных результатов с экспериментальными данными и установлен поправочный коэффициент в зависимости от текущей координаты, максимальное значение которого $k_{t w}=1,78$.

Научная новизна. Доказана целесообразность как в аэродинамическом, так и в аспекте энергосбережения, применения закручено-компактных струй, образованных рекуператором, с утилизацией теплоты выбросного воздуха, в переменном режиме. Эти меры позволят обеспечить комфортные условия в горной шахте и достичь энергосбережения.

Практическая значимость. Использование приточновытяжных рекуператоров с утилизацией теплоты выбросного воздуха позволит проектировать энергосберегаюшие схемы воздухораспределения в системе секционной вентиляции для малогабаритных горных шахт с обеспечением нормативных параметров воздуха в сменном режиме.

Ключевые слова: горная шахта, закручено-компактные струи, приточно-вытяжной рекуператор, воздухораспределение

Recommended for publication by V.P. Korbut, Doctor of Technical Sciences. The manuscript was submitted 25.03.20. 